\title{
Synthesis and Study of 1,2,4-Oxadiazolines derivatives and their Antifungal activity.
}

\author{
${ }^{1}$ Kumar Gaurav Jain and ${ }^{2}$ C. P. Singh \\ 1. Dept of chemistry, Govt Degree college, KotdwaraBhabhar (Uttarakhand) \\ 2. Dept of chemistry, Sahu Jain college, Najibabad(U.P.)
}

\begin{abstract}
Addition of benzonitrileoxide, generatedin situ by the action of triethylamine on benzhydoxamoyl chloride, to 2-hydroxybenzalaniline and its $N$-phenyl derivatives yielded a mixture of products which was separated into two compounds by fractional crystallization. The major products have been found to be the respective cycloadducts and the minor product was identified as the dimer of the starting nitrile oxide. The cycloadducts have been identified as 1,2,4-oxadiazoline derivatives (Ia-Va) on the basis of elemental analysis and spectral studies. The synthesized 1,2,4-oxadiazolines (Ia-Va) were tested in vitro for their antifungal activity against Alternaria alternate, Curvularialunata, Fusariumoxysporumand Myrotheciumroridum by employing the standard technique of spore germination inhibition at various concentrations. Some of the compounds have shown promising antifungal activity against the test fungi.
\end{abstract}

\section{Introduction}

Addition of benzonitrile oxide to benzalanilines and cinnamalanilines results in the formation of 1,2,4oxadiazolines ${ }^{1-3}$ which have been reported to possess fungitoxicity. The presence of electron releasing groups such as methoxy ${ }^{4}$, ethoxy ${ }^{5}$, hydoxy $y^{6}$ etc. in the phenyl ring increases the activity of parent compound like Schiff bases and thiazolidinones. The present investigation was carried out to study the effect of hydroxyl group in the ortho position of C-phenyl ring on the fungitoxicity of 1,2,4-oxadiazolines because it has been reported that the presence of $\mathrm{OH}$ group in ortho position of $\mathrm{N}$-phenyl ring increases the activity of 1,2,4-oxadiazoline ${ }^{7}$ manifold. The results of this study are being communicated in this paper.

\section{Experimental}

Reaction of benzonitrile oxide, generated in situ from benzhydoxamoyl chloride with 2hyroxybenzalaniline.2-Hydroxybenzalaniline(I) $(1.97 \mathrm{~g}, 0.01 \mathrm{~mole})$ was dissolved in ether $(10 \mathrm{ml})$ in a beaker $(250 \mathrm{ml})$ and was cooled in an ice bath at $0^{\circ} \mathrm{C}$. Benzhydroxamoyl chloride $(1.1 \mathrm{~g}, 0.01 \mathrm{~mole})$ was then added to the above solution with constant shaking and the contents were kept at $0^{\circ} \mathrm{C}$ for some time. Triethylamine $(1.2 \mathrm{ml})$ in ether $(20 \mathrm{ml})$ was then added drop-wise with continuous shaking. After complete addition of triethylamine, the reaction mixture was allowed to stand at $0^{\circ} \mathrm{C}$ for 2 hours. The ether layer was separated out and the residue was washed thrice with dry ether. The combined ether layer and the washings on evaporation of the solvent yielded a mixture of products. Fractional crystallization yielded two products. The major product was recrystallized from benzene to get $1,2,4$-oxadiazoline(Ia), m.p. $190^{\circ} \mathrm{C}$ yield $66 \%$.

The reaction of benzonitrile oxide with 2-hydroxybenzal-4-toluidine(II), 2-hydoxybenzal-4anisidine(III), 2-hydroxybenzal-4-phenitidine(IV) and 2-hydoxybenzal-4-chloroaniline(V) was carried out in the similar way to get 1,2,4-oxadiazolines (IIa-Va) respectively. The stock solution (2000 ppm) was prepared by dissolving the compound $(20 \mathrm{mg}$ each) in minimal quantity of ethanol $(0.5 \mathrm{ml})$ and the volume was made up to $10 \mathrm{ml}$ by adding sterilized water. The stock solutions were serially diluted to $1000,500,250,100,50$ and 25 ppm. The cavity slides were used to study the spore germination inhibition by these compounds at different concentrations. The treated spores in cavity slides were kept in perti plates lined with moist filter paper discs and incubated at $24^{\circ} \mathrm{C}$ for 20 hours. The percent spore germination inhibition was recorded by the following formula: 


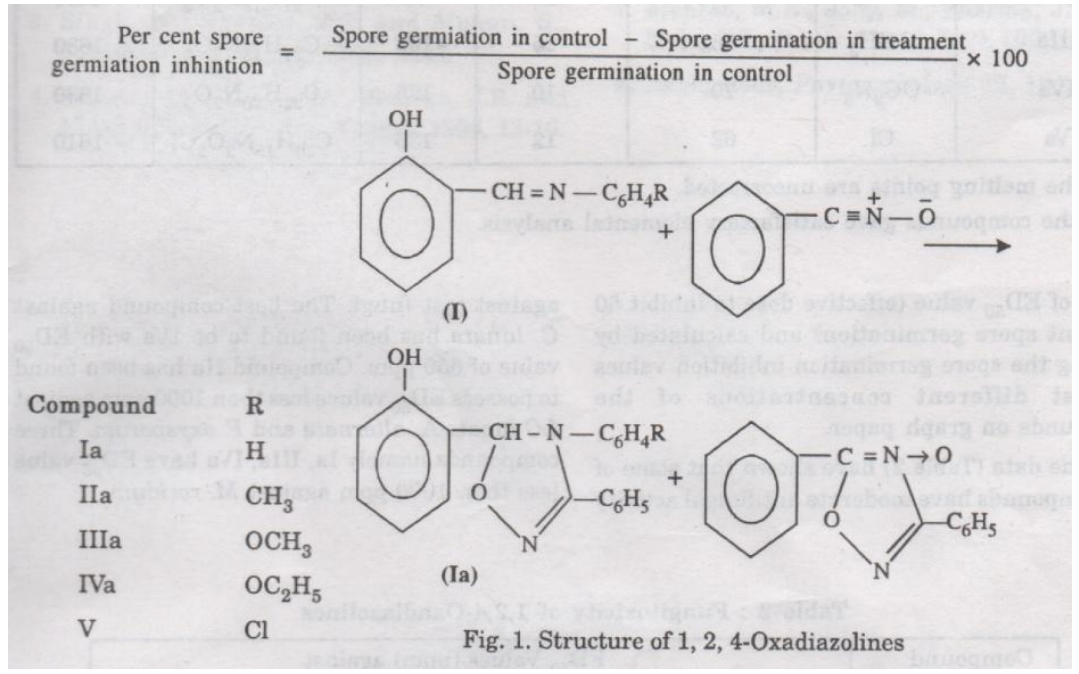

III. Results And Discussion

Addition of benzonitrile oxide, generated in situ from benzhydoxamoyl chloride by the action of triethylamine, to 2-hydoxybenzalaniline and its N-phenyl derivatives (I-V) after usual work up and solvent removal yields solids which have been separated into two compounds in each case. The major products have been found to be the cycloadducts(Ia-Va) and the minor product has been identified as the dimer of the nitrile oxide. The infra-red spectra of the adducts(Ia-Va) show bands at $1630 \mathrm{~cm}^{-1}$ which is indicative of the presence of $-\mathrm{CH}=\mathrm{N}$ - linkage. The PMR spectrum of the adduct IIa indicates a three proton singlet at $4.0 \delta$ for methoxy protons. Aromatic protons along with the protons of the five membered ring are indicated as a multiplet between $6.7 \delta$ to $7.7 \delta$. The PMR spectrum of the compound IIa also contains a three proton singlet at $2.4 \delta\left(\mathrm{CH}_{3}\right.$ protons) and PMR of compound IVa contains a three three proton triplet at $1.6 \delta\left(\mathrm{CH}_{3}\right.$ protons of $-\mathrm{OC}_{2} \mathrm{H}_{5}$ group $)$ and a two proton quartet at $4.4 \delta$ due to $\mathrm{OCH}_{2}$ protons of $\mathrm{OC}_{2} \mathrm{H}_{5}$ group. On the basis of spectral studies and elemental analysis, these compounds are assigned 1,2,4-oxadiazoline structures (Ia-Va). The synthesized 1,2,4oxadiazolines along with their characteristics are recorded in Table 1.The synthesized compounds (Ia-Va) were tested in vitro for their antifungal activity against four phytopathogenic fungi viz., Alternaria alternate, Curvularialunata, Fusariumoxysporum and Myrotheciumroridium by spore germination inhibition method ${ }^{8-11}$.

\begin{tabular}{|c|c|c|c|c|c|c|}
\hline \multirow{3}{*}{ Compound } & \multicolumn{3}{|c|}{$\begin{array}{l}\text { J. Indian Council of Chemists, } \\
\text { Table } 1 \text { : Characteristics of } 1,2 \text {, }\end{array}$} & \multicolumn{2}{|c|}{$\begin{array}{l}\text { Wol. 19, No. 1, } 2002 \\
\text { 4-Oxadiazolines }\end{array}$} & \multirow{3}{*}{$\begin{array}{l}\text { IR band } \\
\left(\mathrm{cm}^{-1}\right)\end{array}$} \\
\hline & \multirow[t]{2}{*}{$\therefore \mathrm{R}$} & \multicolumn{2}{|c|}{ Yield (\%) } & \multirow{2}{*}{$\begin{array}{l}\text { m.p. }{ }^{*} \\
\left({ }^{\circ} \mathrm{C}\right)\end{array}$} & \multirow{2}{*}{$\begin{array}{l}\text { Molecular } \\
\text { Formula** }\end{array}$} & \\
\hline & & Compound & Dimer & & & \\
\hline Ia ${ }^{e}$ & $\begin{array}{l}\mathrm{H} \\
\mathbf{H}\end{array}$ & $\begin{array}{ll}\therefore 6 \\
4\end{array}$ & 12 & 190 & $\mathrm{C}_{20} \mathrm{H}_{16} \mathrm{~N}_{2} \mathrm{O}_{2}$ & \multirow{5}{*}{$\begin{array}{r}1620 \\
1630 \\
1630 \\
1630 \\
1610\end{array}$} \\
\hline IIa & $\mathrm{CH}_{3}$ & 58 & 14 & 92 & $\mathrm{C}_{21} \mathrm{H}_{18} \mathrm{~N}_{2} \mathrm{O}_{2}$ & \\
\hline IIIa & $\mathrm{OCH}_{3}$ & 55 & 15 & 105 & $\mathrm{C}_{2 \mathrm{I}} \mathrm{H}_{18} \mathrm{~N}_{2} \mathrm{O}_{3}$ & \\
\hline $\mathrm{IVa}, 82$ & $\mathrm{OC}_{2} \mathrm{H}_{5}$ & 70 & $10, \lambda$ & 125 & $\mathrm{C}_{22} \mathrm{H}_{20} \mathrm{~N}_{2} \mathrm{O}_{3}$ & \\
\hline Va & $\mathrm{Cl}$ & 62 & 12 & 135 & $\mathrm{C}_{20} \mathrm{H}_{15} \mathrm{~N}_{2} \mathrm{O}_{2} \mathrm{Cl}$ & \\
\hline
\end{tabular}

Dithan M-45 and Bavistin were used as check to compare the activity of the compounds. The antifungal activity has been expressed in terms of $\mathrm{ED}_{50}$ value (effective dose to inhibit 50 percent spore germination) and calculated by plotting the spore germination inhibition values against different concentrations of the compounds on graph paper.

The data (Table2) have shown that some of the compounds have moderate antifungal activity against test fungi. The best compound against $\mathrm{C}$. lunata has been found to be IVa with $\mathrm{ED}_{50}$ value of $650 \mathrm{ppm}$. Compound IIa has been found to possess $\mathrm{ED}_{50}$ values less than 1000ppm against $\mathrm{LC}$ lunata $\mathrm{A}$. alternate and $\mathrm{F}$. oxysporum. Three compounds namely Ia, IIIa, IV a have $\mathrm{ED}_{50}$ value less than $1000 \mathrm{ppm}$ against $\mathrm{M}$. roridum. 
Synthesis and Study of 1,2,4-Oxadiazolines derivatives and their antifungal activity.

\begin{tabular}{|c|c|c|c|c|}
\hline \multirow{2}{*}{ Compound } & \multicolumn{4}{|c|}{$\mathrm{ED}_{50}$ Values (ppm) against } \\
\hline & $\begin{array}{c}\text { Curvularia } \\
\text { lunata }\end{array}$ & $\begin{array}{l}\text { Alternaria } \\
\text { alternata }\end{array}$ & $\begin{array}{c}\text { Fusarium } \\
\text { oxysporum }\end{array}$ & $\begin{array}{c}\text { Myrothecium } \\
\text { roridum }\end{array}$ \\
\hline Ia & * & * & * & 980 \\
\hline $\mathrm{IIa}$ & 780 & 810 & 750 & * \\
\hline IIIa & 790 & * & $*$ & 880 \\
\hline IVa & 650 & $*$ & $*$ & 990 \\
\hline $\mathrm{Va}$ & a & $*$ & $*$ & * \\
\hline Bavistin** & - & 一 & 9 & - \\
\hline $\begin{array}{l}\text { Dithane*** } \\
\mathrm{M}-45\end{array}$ & 39 & 35 & - & 30 \\
\hline
\end{tabular}

\section{References}

[1]. Rai, M., Krishan, K. and Singh, A., Indian J. Chem., 15B, 1997, 848.

[2]. Krishan, K., Rai, M., Singh, J. and Singh, A., Indian J. Chem., 15B, 1997, 1041

[3]. Singh, N., Sandhu, J.S. and Mohan. S., Tetrahedron Lett., 42, 1968, 4453.

[4]. Manro, M.R., Jolly, M., Sharma, J.R. and Kalsi, P.S., Pestic. Res. J., 8(1), 1996, 13-16.

[5]. Manro, M.R., Gill, K.K., Sharma, J.R. and Kalsi, P.S., Pestic. Res. J., 12(2), 2000, 239-41.

[6]. Manrao, M.R., Singh, B., Sharma, J.R. and Kalsi, P.S., Pestic. Res. J., 7(2), 1995, 157-59.

[7]. Manrao, M.R., Jolly, M., Sharma, J.R. and Kalsi, P.S., Pestic. Res. J., 9(2), 1997, 231-34.

[8]. Anonymous, Phytopathology, 33, 1943, 627.

[9]. Jain, N.; Kashaw S.K.; Agarwal, R.K.; Gupta, A. Synthesis, anticonvulsant and neutrotoxic activity of some new 2,5-disubstituted1,3,4-oxadiazoles, Med,Chem. Res. 20,1696-1703. (2011)

[10]. Sangshetti, J.N.; Chabukswar, A.R.; Shinde, D. B.Microwave assisted one pot synthesis of some novel 2,5-disubstituted 1,3,4oxadiazoles as antifungal agents. Bloorg. Med. Chem. Lett. 21,444-448. (2011)

[11]. Saini MS, Singh R, Dwivedi J, Kumar A. Synthesis and Biological activity of some N-Benzylidene Derivatives of 2-Aryl-5Hydroxy-7-Methyl-1,2,4-Triazolo-[1,5-a]- Pyrimidines. Inter. J. Scie. Nature.;3(4);925-927.(2011) 